\title{
Dina Dreyfus, Alain Badiou e os programas de Filosofia da Rádio-Televisão Escolar francesa nos anos 1960. Entrevista com Alain Badiou
}

\section{Luciana Portela}

\section{(2) OpenEdition Journals}

Edição electrónica

URL: http://journals.openedition.org/aa/3537

DOI: $10.4000 /$ aa.3537

ISSN: 2357-738X

Editora

Programa de Pós-Graduação em Antropologia Social (UnB)

\section{Edição impressa}

Data de publição: 1 junho 2019

Paginação: 331-346

ISSN: 0102-4302

\section{Refêrencia eletrónica}

Luciana Portela, «Dina Dreyfus, Alain Badiou e os programas de Filosofia da Rádio-Televisão Escolar francesa nos anos 1960. Entrevista com Alain Badiou», Anuário Antropológico [Online], v.44 n.1 | 2019, posto online no dia 06 julho 2019, consultado o 28 abril 2021. URL: http://journals.openedition.org/aa/ 3537 ; DOI: https://doi.org/10.4000/aa.3537

\section{(c)}

Anuário Antropológico is licensed under a Creative Commons Atribuição-Uso Não-Comercial-Proibição de realização de Obras Derivadas 4.0 International. 
329

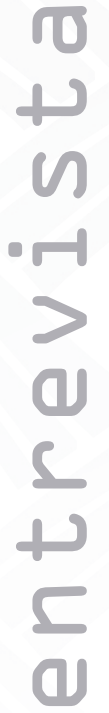





\title{
Dina Dreyfus, Alain Badiou e os programas de Filosofia da Rádio-Televisão Escolar francesa nos anos 1960 Entrevista com Alain Badiou
}

\author{
Luciana Magalhães Portela \\ Universidade de Brasília - Brasil \\ com a participação de Isabelle Vodoz ${ }^{1}$ \\ Instituto de Alemão da Universidade Sorbonne Nouvelle, Paris III - França
}

\section{Apresentação}

Dina Dreyfus é conhecida no Brasil - quando o é - por ter sido esposa de Lévi-Strauss, e, quando muito, por ter participado da Missão Pesquisas Folclóricas ou da fundação da Sociedade de Etnografia e Folclore no Brasil, ao lado de Mário de Andrade, na década de 1930. Pouco se sabe sobre sua trajetória após seu retorno à França. Ao iniciar minha pesquisa sobre Dreyfus ${ }^{2}$, tive acesso às informações relativas ao período em que morou no Brasil, reunidas por pesquisadores que, como Mariza Côrrea $^{3}$, Luísa Valentini ${ }^{4}$, Mariana Sombrio ${ }^{5}$ e Luis Donisete Grupioni ${ }^{6}$, contribuíram para nos informar sobre a relevância do seu trabalho e a paradoxal invisibilidade tecida pela historiografia das ciências sociais a seu respeito. As menções feitas a ela no Brasil se debruçam principalmente sobre sua jornada como etnóloga, ainda que ela tenha consagrado a maior parte de sua vida à filosofia. Foram aproximadamente 50 anos de dedicação à pesquisa, ao ensino, à produção escrita e audiovisual, dentre os quais apenas quatro no campo da etnologia. Portanto, esta entrevista tem como finalidade abordar uma parte de sua trajetória profissional ainda pouco explorada. Pretendo, com isso, complementar a produção acima mencionada, mas também evitar a redução da sua trajetória aos curtos anos em que atuou em parceria com o ex-marido.

Para tentar compreender sua trajetória, foi necessário pesquisar material referente ao período que segue o seu retorno à França. Tais informações encontram-se, no entanto, espalhadas nas mais variadas fontes ${ }^{7}$. Além disso, poucas são as pessoas que a conheceram e que ainda hoje estão vivas.

Alain Badiou tinha aproximadamente 26 anos quando foi convidado por Dreyfus para encarnar o personagem do jovem filósofo ${ }^{8}$ na série de televisão concebida por ela, intitulada L'enseignement de la philosophie, difundida pela Radio-Télévision 
Scolaire (RTS) na década de $1960 .{ }^{9}$ Ao apresentar autores renomados discutindo temas atuais com Badiou, Dreyfus visava distanciar-se da visão limitada da filosofia, como um conhecimento restrito aos pensadores clássicos. ${ }^{10}$

Badiou nasceu no Marrocos em 1937 e se instalou em Toulouse, na França, ainda na infância. Estudou na École Normale Supérieure - ENS, em Paris, onde teve formação abrangente - ciências sociais, filosofia, psicologia, linguística e literatura. Durante a sua formação na ENS, Badiou teve também atuação importante em movimentos de militância política, como, por exemplo, contra a guerra colonial na Argélia. Em 1960, recebeu o título de Agregé ${ }^{11}$ em Filosofia e no ano seguinte foi nomeado professor no Lycée ${ }^{12}$ de Reims, alguns anos antes de ser convidado para trabalhar na RTS. Foi um dos fundadores do Departamento de Filosofia da Universidade de Paris VIII, em 1969, juntamente com Michel Foucault, Jacques Rancière e Gilles Deleuze. Badiou é professor emérito da ENS e, além das publicações em filosofia, escreveu romances e peças de teatro ${ }^{13}$. Com oitenta e um anos, Badiou continua a publicar livros e numerosas entrevistas. Entre suas principais publicações traduzidas para o português, podemos citar: Para uma nova teoria do sujeito ${ }^{14}, \mathrm{O}$ ser e o evento ${ }^{15}$ e $O$ século $^{16}$. Em maio desse ano, publicou o livro On a raison de se révolter ${ }^{17}$, uma reflexão sobre os eventos de maio de $1968^{18}$.

Ao estabelecer um contato inicial com Badiou, fui direcionada a Isabelle Vodoz, que se encarregou de fazer a mediação. Vodoz é professora aposentada do Instituto de Alemão da Universidade Sorbonne Nouvelle, Paris III e traduziu textos de Badiou, Slavoj Zizek e Jürgen Habermas. Organizou também obra que reúne artigos de diversos autores sobre Badiou ${ }^{19}$. Vodoz é uma colaboradora próxima do filósofo - como pode ser observado no livro A República de Platão recontada por Badiou ${ }^{20}$, em que o autor afirma que ela não só transcreve o texto mas tem participação efetiva, contribuindo com marcações e observações. Vodoz está presente em diversas entrevistas ao lado de Badiou, incluindo a que apresento a seguir, da qual participou ativamente, contribuindo no enriquecimento do diálogo.

O relato de Badiou nos apresenta uma face de Dina Dreyfus ainda pouco conhecida, já que no encontro ficou evidente a amizade que os uniu e o reconhecimento que ele guarda pela sua confiança nos anos iniciais de sua carreira. A fala de Badiou nos traz algo mais de Dreyfus, sobre como ela poderia ser adorável e severa, sua dedicação aos estudantes e ao ensino da filosofia.

Nas linhas a seguir relato trechos selecionados da entrevista realizada com o filósofo no dia 11 de janeiro de 2018, em Paris, na residência de Isabelle Vodoz. A 
presente edição se deve ao fato da longa extensão do material bruto gravado, mas também por uma opção de dar lugar à trajetória profissional de Dreyfus e aos vínculos profissionais tecidos entre eles, objetivo que conduziu a entrevista.

Luciana Portela: No decorrer da minha pesquisa, me deparei com a atuação de Dina Dreyfus nos programas de filosofia da RTS e sua parceria com o senhor. Como a maior parte das referências que tenho de Dreyfus se refere à sua atuação como etnóloga no Brasil na década de 1930, gostaria de saber mais sobre o prosseguimento do seu percurso profissional na França.

Alain Badiou: Eu conheci Dina Dreyfus pessoalmente durante um período muito específico, que vai de 1963 a 1971, mais ou menos.... Na verdade, estava totalmente ligado à questão das edições da televisão escolar. Então, em um primeiro momento, cabe a pergunta: por que fui eu que embarquei nesse projeto? Na verdade, ela teve, logo no início, a ideia de que esses programas de televisão deveriam reproduzir alguma coisa dos diálogos de Platão, em que veríamos um filósofo estabelecido discutir com um jovem. Então a questão era saber quem seria esse jovem? Eu fui escolhido, por razões puramente acadêmicas, pois os grandes amigos de Dina Dreyfus na Universidade eram [Georges] Canguilhem e [Jean] Hyppolite. Os dois eram amigos muito próximos dela. Eu me lembro sempre de Dina chegando no curso de Canguilhem... não éramos muito mais do que 20 alunos. Eles estavam sempre lá. Como Canguilhem fazia parte da banca da Agregação, havia dito à Dina que esse jovem, Badiou, era muito bom, conhecia tudo. Então fui contratado sem saber o que era pretendido, pois eu não tinha nenhum contato com a televisão. Na minha família não havia televisão, meus pais eram hostis à televisão. Eu nunca assistia televisão! A ideia de Dina era muito precisa, ela queria fazer diálogos sobre um tema específico, entre um filósofo reconhecido e um jovem, destinados a serem projetados nos estabelecimentos escolares em uma hora determinada. Naquela época não havia discos, não havia gravações. Então era a televisão nacional pública que, em uma hora específica, que correspondia à hora das aulas, projetava o programa. Eu levava meus alunos, que ficavam muito contentes de ver o seu professor na tela. Isso aumentou muito minha popularidade! A gente começou pelos amigos mais próximos da Dina. Fizemos o programa com o Hyppolite, o primeiro, eu acho, sobre o que é a filosofia. Em seguida, fizemos um programa com Canguilhem, e depois com Foucault, porque ele era o discípulo preferido de Canguilhem. É preciso saber também que 
Dina era Inspetora Geral de Filosofia e então, enquanto Inspetora, conhecia bem o mundo dos professores de filosofia, incluindo o ensino secundário.

Isabelle Vodoz: Desculpem-me, poderia interromper? Porque não é óbvio se tornar inspetora. Por que ela se tornou inspetora, sendo que era antropóloga antes? Como isso se deu?

Alain Badiou: Ela era Agrégée de Filosofia, era o seu métier. Ela tinha se tornado antropóloga por amor ao Lévi-Strauss... é preciso ver as coisas como elas são. Ela foi antropóloga durante o período em que acompanhou Lévi-Strauss no Brasil. Mas quando ela e Lévi-Strauss se separaram, acredito que tenha sido um trauma para ela. Você deve conhecer melhor do que eu essa parte. É a impressão que eu tive das poucas vezes que ela me falou, pelo menos um pouco... A gente vai voltar nisso. Ela voltou à França e depois das peripécias ligadas à Guerra, se tornou professora de Filosofia. Como era uma excelente professora de Filosofia, a Inspeção Geral a recrutou, e então ela se tornou inspetora geral da região parisiense, na época era um sistema assim. E como Inspetora Geral, ela conhecia muito bem o meio dos professores de filosofia, a pedagogia da filosofia, a aula de filosofia e queria realmente dedicar a televisão à aula de filosofia. Então a gente gravava os programas em condições antigas, era um estúdio. Era, obviamente, em preto e branco. Tinha um diretor ${ }^{21}$ - cujo nome me escapa agora, mas eu devo me lembrar - que acompanhou todo o processo. Nessa época eu era professor do Lycée de Reims, então eu também estava no ensino secundário, nas turmas de terminale ${ }^{22}$ e fizemos uma série de programas entre 1965 e 1967, com ambições cada vez maiores. No início eram realmente diálogos entre eu e o filósofo e depois passou a ter coisas um pouco mais complicadas, com trios, e depois o programa sobre a verdade, o mais complexo, com Foucault, Hyppolite, Ricœur, a própria Dina - é a única vez que ela aparece na tela - e eu. Esses programas eram produzidos pelo Instituto Nacional Pedagógico e projetados nas salas de aula. Eu mesmo os vi diversas vezes com meus alunos. Sabíamos que às dez horas, na sala de aula onde havia uma tela de televisão, veríamos a discussão. Então, isso me deu um papel particular, porque para todos os professores de filosofia que viam o programa, ou que projetavam o programa, eu era um "cara qualquer", mas na verdade eu já era professor de filosofia... então era de certa forma, um pouco "falseado". Eu fazia o papel do discípulo que interroga o mestre. Nessa época, então, eu frequentei muito a casa de Dina, pois tínhamos 
que discutir, a cada vez, quem é que viria ao programa, quando seria o programa. E evidentemente, eu almocei com ela, conversávamos, dormi na casa dela diversas vezes. Então nós tivemos uma amizade, realmente, durante todo esse período. Foi assim que ela me falou um pouco sobre outras coisas para além dos programas de televisão. Ela me falou da sua ligação com Lévi-Strauss. Tenho que admitir que ela me colocou numa situação um pouco embaraçosa, pois me disse que eu parecia muito com ele. Não fisicamente, mas intelectualmente... Eu não sei se foi um elogio ou uma crítica (risos). Ela me falou disso e também conversamos muito sobre literatura. Principalmente os seus romancistas favoritos: Conrad, Faulkner, esses grandes astros da literatura. Ela leu meus primeiros livros, em especial Portulans, meu segundo romance que, coincidentemente, foi publicado na mesma época das gravações. E ela tinha lido também Almagestes, o meu primeiro livro, porque o mundo do romance a interessava muito. A gente conversou sobre muitas coisas nessa época e o que nos separou foi 68. Não maio de 1968, especificamente, mas os anos que seguiram, em que eu só fiz política, e era uma política que não convinha a ela. Ela era muito mais tradicional no que diz respeito a um ponto sobretudo: no fundo, o sentido da sua vida era de defender o ensino da filosofia. Era realmente uma paixão para ela. E ela estimava que, na crítica que os jovens faziam aos estudos, a crítica à universidade, a tudo, havia algo de ameaçador que não a agradava. Um episódio que foi muito negativo na nossa relação foi o ano em que se decidiu proibir a Agregação. Foi decidido pelos esquerdistas que o exame de Agregação seria proibido por ser um exame totalmente seletivo. Como eu participava desse movimento, fiquei muito mal visto por ela porque a gente interrompeu a Agregação pela qual ela tinha uma verdadeira paixão. Era um mundo ao qual ela pertencia, mas pertencia também Ricœur, e talvez até mesmo eu, Hyppolite certamente. Era um mundo muito instalado nas estruturas do ensino superior nessa época. Então, em seguida, só nos vimos em situações esporádicas. Mas eu tinha realmente o sentimento de que tínhamos nos desentendido, porque a relação que ela tinha pelo ensino tradicional era muito forte, muito clássica, muito defensável. Aliás, isso não é uma crítica pessoal a Dina Dreyfus. Sei que ela tinha tentado inventar uma coisa nova, colocando a televisão. Era uma professora adorada pelos seus alunos, uma professora formidável.

Luciana Portela: Eu penso também no lugar das mulheres na época, você acha que ela queria abrir espaço para as mulheres no ensino? 
Alain Badiou: Sim, eu acho. Ela não pensava as coisas como um conflito entre homens e mulheres. Mas ela queria afirmar, de toda forma, que as mulheres poderiam muito bem estar no sistema, na direção, na universidade. Ela era feminista nesse sentido, era feminista igualitária. Ela queria realmente assumir a sua função, e de fato, é preciso reconhecer que as mulheres nessa época eram raras no nível em que ela se encontrava, principalmente na administração da Inspeção Nacional. Esta era extraordinariamente pouco feminizada, eu acredito que ela fosse a única mulher em todo o sistema. Eu, pelo menos, não conheci outra. E o fato de estar lá no fim dos anos 1960, ou mesmo no fim dos anos 1950, era absolutamente excepcional. Ela era também protegida e apreciada pelos "bons". Eu sempre a vi muito à vontade com Canguilhem, Hippolyte, Foucault, Michel Serres, etc. Ela se portava de igual para igual com eles. Tínhamos a impressão que ela defendia o seu lugar, mas não era agressiva. Ela o fazia com grande simplicidade, naturalmente, mas era uma mulher com o julgamento muito estrito, muito severo. Quando ela julgava alguma coisa, ou ainda, julgava negativamente, ninguém a fazia mudar de ideia facilmente. Eu apreciava isso. Não digo isso enquanto crítica, era uma mulher que argumentava, mas quando tinha encontrado argumentos sólidos para alguma coisa, mantinha sua posição de maneira absolutamente segura.

Luciana Portela: Será que poderíamos voltar um pouco no tempo? Meu primeiro contato com Dina Dreyfus se deu por meio da leitura de autores ${ }^{23}$ que trataram das expedições e coleções que ela realizou no Brasil com Claude Lévi-Strauss. Me chamou a atenção nunca ter ouvido falar dela antes: ela havia sido aluna de Marcel Mauss em seu curso de etnologia, ela conhecia, portanto, as técnicas, ela fazia os contatos no Brasil que viabilizaram as expedições. Depois sei que ela partiu do Brasil, em meio à segunda expedição em função de uma infecção no olho. E depois há uma lacuna. O senhor poderia me ajudar a reconstituir essa lacuna da história de Dreyfus, entre a experiência no Brasil e sua atividade como Inspetora de Filosofia após seu retorno à França?

Alain Badiou: Eu também não sei o que aconteceu entre o período em que ela retornou e o momento em que a conheci, salvo o fato de que já havia ouvido falar dela como Inspetora Geral. Eu era ainda jovem nessa época. Eu não sabia muito em relação à sua história anterior. Mas de fato, também me perguntei: o que exatamente aconteceu naquele momento? No fundo eu não sabia muito bem. Sabia que 
ela era professora de filosofia em um certo momento, e depois que ela tinha sido Inspetora Geral. Além disso, das conversas que tivemos, o Brasil ou a Antropologia não estavam em pauta, ou pouco, muito pouco. É como se tivesse havido um "blackout" porque estava associado a uma verdadeira prova. Também tive o sentimento indireto - não foi ela quem me disse - conhecendo um pouco melhor o que tinha se passado, tive a impressão de que uma parte da missão Lévi-Strauss no Brasil foi ela quem fez. Eu tenho a impressão de que ela teve um papel determinante nesse assunto. Agora, se ela teve a impressão em algum momento que o seu trabalho havia sido captado por Lévi-Strauss? Eu não sei... Mas do ponto de vista das operações de campo, dos conhecimentos, ela teve um papel absolutamente fundamental. De forma que me surpreendeu que ela não falasse mais de antropologia. Ela tinha se convertido à filosofia clássica. Mas, ao final, ela estava bem distante da antropologia. Acredito que isso seja, de certa forma, uma consequência da experiência brasileira.

Luciana Portela: Uma ruptura? Como se ela tivesse tomado a ruptura com Lévi-Strauss como uma ruptura com a Antropologia?

Alain Badiou: Eu concordo com a sua hipótese. É o sentimento que eu tive, pelo menos...

Luciana Portela:Tem uma coisa interessante nos cadernos de campo da Dina: trechos de um romance que ela queria escrever.

Alain Badiou: Mas isso eu sei, que ela queria escrever um romance. Ela tinha me falado quando a gente conversava sobre romances. Ela tinha me dito, mas sem me dizer nada além disso, que ela tinha desejado, ou que ela desejava - já não sei mais se era no passado ou no presente - ser romancista. Por outro lado, seu interesse pelo romance era extremamente forte quando a conheci. Fora da Filosofia, dos programas de televisão, quando a gente conversava, conversava muitas vezes sobre romance.

Isabelle Vodoz: Posso te fazer uma pergunta? Em que ano ela nasceu?

Luciana Portela: 1911. 
Isabelle Vodoz:Vocês tinham então 26 anos de diferença [para Alain Badiou].

Alain Badiou: Sim.

Isabelle Vodoz: É que, quando a gente pensa, quando a gente fala assim, é claro que um jovem hoje faria até mesmo outras perguntas, mas na época, antes de 1968, você poderia ouvir confidências sobre qualquer coisa, mas não ousaria fazer perguntas aos adultos! Está vendo o que eu quero dizer? Talvez hoje em dia, faríamos isso de maneira mais aberta... mas na época, ela tinha quase a idade dos nossos pais.

Luciana Portela: No programa Filosofia e Verdade (Philosophie et vérité), pude notar um olhar de cumplicidade entre o senhor e a Dina Dreyfus: ela sorri, ela te olha como se estivesse dizendo: "Está funcionando!" (risos).

Alain Badiou: O que me chama atenção nessa edição é que eu é que concluo, sou eu quem conclui. Senti, quando a gente fez esse programa, que ela direcionava para isso, com alguns sinais. Ela não queria que a conclusão fosse dos outros. Aliás, Foucault vai embora no meio do episódio, desce as escadas e desaparece... Sobrou Ricœur e Hyppolite, mas eu via claramente que, para a Dina, era eu quem iria concluir, e efetivamente, sou eu quem conclui. Quando olho isso, penso comigo mesmo: "Eu era muito corajoso, na época" (risos)!

Isabelle Vodoz: Teve alguém que você gostaria de ter convidado para o programa que ela não queria, ou o contrário?

Alain Badiou: Na verdade, não.

Isabelle Vodoz: Eu me lembro que tinha o [Raymond] Aron, o [Jean-Paul] Sartre...

Alain Badiou: Ah, não, não teve o Sartre!

Isabelle Vodoz: E por quê?

Alain Badiou: Eu nunca soube se ela que não quis chamá-lo, ou ele é que não quis. Por outro lado, fizemos algo indireto sobre o [Jacques] Lacan. Mas eu acho que era 
um programa de rádio, não era na série dos filmes. Acho que ela não queria também dar a impressão de que tinha feito uma escolha política. É por isso que Aron, que era um conservador, veio, e foi tudo bem. E dentre os jovens, teve [Paul] Ricœur. $\mathrm{Na}$ verdade, ela tinha seus gostos, e eu acho, por exemplo, que ela não gostava de Sartre. Não muito.

Luciana Portela: Foi ela quem concebeu a ideia dos programas?

Alain Badiou: Ah, sim, absolutamente! Era seu projeto, que ela conseguiu impor pelo fato de ser Inspetora Geral. Por isso ela era muito apegada, e trabalhamos muito nele. E eu pude experimentar a eficácia com meus alunos.

Luciana Portela: Por que o senhor acha que era eficaz?

Alain Badiou: Porque acho que os introduzia na Filosofia de uma maneira mais adaptada ao mundo deles do que simplesmente as aulas. Eles viam ali um jovem, porque eu não era assim tão mais velho que os alunos. Eles tinham 18 anos e havia ali um jovem que falava com os filósofos mais ou menos conhecidos. Eu fazia uma pequena apresentação: "vocês vão ver o Senhor Hyppolite, que fez isso, o grande tradutor de tal obra...”. Acho realmente que tinha uma identificação. Tinha alguma coisa que acontecia no diálogo que era diferente das aulas. Depois de assistir aos filmes, tínhamos discussões interessantes com os alunos.

Luciana Portela: Eu li em uma revista que falava dos programas de televisão de filosofia nos anos 1980, e que falava também desses primeiros programas dos anos $1960 \ldots$

Alain Badiou: Foram os primeiros! Realmente!

Luciana Portela: ... e havia algo nesse artigo ${ }^{24}$ sobre o poder das imagens, sobre a importância de, para além de ouvir a pessoa entrevistada falar, ver a pessoa se mexer, ver a boca, os olhos, ver realmente a pessoa.

Alain Badiou: Certamente, pois eu acredito que Dina Dreyfus tinha a ideia de que o sentido da filosofia era o ensino. É muito mais que os livros. Ela amava os livros, 
claro, lia livros como todo mundo, mas ela pensava que a verdade da filosofia, desde Sócrates, era a palavra viva.

Isabelle Vodoz: É bem o que você pensa também!

Alain Badiou: Eu também penso assim, ainda que os livros sejam indispensáveis, não podemos fazer de outro jeito. Mas tem um elemento de presença do corpo do filósofo que faz parte da transmissão filosófica. Porque no livro, você pode sempre desconfiar que há artifícios, retórica, que se o filósofo está em dificuldade vai te empurrar um argumento. Eu dei milhares de aulas de filosofia na minha vida... (risos) e quando se está presente, sabe-se que o grau de convicção que se tem, vai ser transmitido. Isto é, o fato de que o que se diz é realmente o que se pensa é visível. Um mau professor é um professor que fala sem convencer os alunos que aquilo que ele pensa realmente é aquilo que ele está contando. Ele faz o seu trabalho, e é isso! Eu sempre concebi um sentido de filosofia, até mesmo com os jovens, até nos cursos de terminale, de que você tem que estar engajado. Você tem que lhes transmitir que é importante ter convicções, argumentar, os dois ao mesmo tempo. Não uma convicção qualquer, mas uma convicção que você possa defender e outras concepções que possa criticar. Apesar de tudo, nesses programas de televisão, tinha esse elemento. Eu acho que ela tinha razão em dizer que ver o corpo dos filósofos, sua boca, sua maneira de falar, ver a maneira como eles fumam o seu cigarro... (risos). Fuma-se nesses programas!

Luciana Portela: Já hoje...

Alain Badiou: Isso seria impensável! Ver também a maneira como ele se dirige ao mesmo tempo a mim e ao público que assiste. Acho que tudo isso era interessante e eu verifiquei nas aulas, isso os interessava. Eles achavam interessante, divertido também. Eles observavam os defeitos de um e de outro, notavam os sotaques, o chiado do Hyppolite... É uma boa ideia, eu realmente acredito.

Isabelle Vodoz: Se posso complementar, havia muito menos programas de televisão...

Alain Badiou: A gente estava menos imerso! Era mais raro!

Isabelle Vodoz: Hoje eu acredito que os alunos não ficariam tão fascinados por um 
programa de televisão como os daquela época.

Alain Badiou: É verdade! Mas de certa forma, não acredito que se façam mais programas de televisão como aqueles...

Isabelle Vodoz: A gente fez um na Suíça sobre a Filosofia ${ }^{25} \ldots$

Alain Badiou: Justamente, eu fiz um em Zurique. Foi incrível, pois quando eu revi esse programa, me lembrou essa época. E quando a gente o vê, se surpreende. Mas justamente, foi a Rádio Zurich que fez um programa muito particular, inteiramente dedicado à filosofia, que é transmitido no domingo.

Luciana Portela: Eu acho também que antes tínhamos menos acesso às imagens, comparado a hoje, com a internet... se alguém fala de uma pessoa que eu não conheço, imediatamente posso ir na internet e...

Alain Badiou: Ah, sim! A gente pode ver imagens o quanto quisermos! Enquanto que, naquela época, eles eram convocados, era uma oportunidade rara. Eles viam uma coisa que nunca tinham visto antes... isso tinha uma força!

Luciana Portela: Percebi que o senhor também tem muitos vídeos de entrevistas atualmente disponíveis na internet, na televisão, bem como muitas aparições nas rádios francesas. Em seu livro, Tamara Chaplin ${ }^{26}$ fala da importância dos programas de filosofia na televisão na França e é, realmente, surpreendente a quantidade desses programas. Gostaria que o senhor falasse um pouco mais sobre a relação entre filosofia e imagem, ou então, a difusão da filosofia pelos programas de rádio ou de televisão.

Alain Badiou: Não é a imagem no geral, porque desse jeito a gente poderia imaginar que seria possível ilustrar a Filosofia, que enquanto alguém fala da natureza, vão mostrar uma paisagem... (risos). Não é a imagem em si, mas a questão do corpo do filósofo. A presença do corpo do filósofo que acredito que seja muito antiga, porque na realidade, a filosofia, desde o início, sempre foi um ensinamento. Sempre houve o filósofo com os discípulos, sempre houve uma presença. A memória dessa presença está nos livros. Sócrates não escreveu nada! Mas virou uma lenda. Temos 
contato com Sócrates a partir de Platão. Porque Platão o tornou um personagem da Filosofia. Eu realmente acredito que a aula de Filosofia é a célula fundamental da Filosofia, essa era a ideia de Dina Dreyfus. A sala de aula de Filosofia era um lugar absolutamente sagrado: ninguém tinha o direito de entrar nela. E pronto! O professor de Filosofia rodeado com os discípulos na sala de aula, etc. Ela me falou várias vezes: "é um espaço sagrado". No fundo, eu concordava. Isso me lembra uma anedota, uma história de família, uma lenda do meu bisavô. Toda a minha família paterna era camponesa. Meu bisavô foi o primeiro a estudar e virou professor. Depois meu avô foi professor e meu pai, professor... (risos). Então são quatro gerações de pedagogos. Na época do meu bisavô, época de Napoleão Terceiro, a igreja católica ainda tinha o direito de inspecionar as aulas para saber se a moral estava sendo respeitada. Meu bisavô dava aulas em um vilarejo no interior, e o pároco local veio para inspecionar. A história é que meu bisavô o pegou pelos ombros e o botou para fora lhe dizendo: "Na sala de aula eu sou o único mestre!". Eu acho que isso foi muito Dina Dreyfus! (risos) Pois ela também pensava que ELA era a única mestra!

Luciana Portela: Falando sobre a presença do professor, penso nos relatos de alunos e colegas de Dina Dreyfus ${ }^{27}$. Todos rememoram sua presença como professora, muito marcante.

Alain Badiou: Muitos se lembram dela como tendo uma presença muito forte, eu pessoalmente também.

Luciana Portela: Sabemos também que Dreyfus ao chegar ao Brasil, em 1935, pleiteou uma vaga de professora na Universidade de São Paulo. Porém seus colegas, que eram homens, conseguiram a vaga e ela não. Me parece que o fato dela ser mulher constituiu-se um impedimento, não somente para assumir essa vaga, mas também para o alcance de um renome. Afinal, ela desenvolveu diversos projetos, tanto no Brasil quanto na França, com todos esses homens que se tornaram proeminentes tanto na Filosofia quanto na Antropologia, enquanto ela é de certa forma muito pouco conhecida.

Alain Badiou: Sim, o fato de ela ser uma mulher com certeza influenciou. Mesmo na França, isso também teve influência. Mas eu sei também que Canguilhem tentou várias vezes convencê-la a fazer uma tese para poder passar para o ensino superior. 
Ele defendia essa ideia, e isso eu tenho que dizer que, pelo menos Hyppolite, Canguilhem e mesmo Aron estariam prontos a apoiá-la. Acho que não se pode pensar que eles a teriam impedido. De forma alguma! Eles a teriam apoiado: tinham uma relação de admiração por ela e por tudo o que ela fazia. Tenho o sentimento de que sua aventura no Brasil a havia distanciado dessa perspectiva. Ela tinha sido professora do Lycée, e depois esteve na Inspeção Geral, e eu nunca senti nela a ideia de voltar a trabalhar um campo filosófico particular. Ela estaria certamente muito mais tentada a escrever um romance. Mas, fazer uma tese, tenho a impressão de que isso não a convinha. Mas quero lembrar, para ser justo, que não foi um impedimento institucional. Sei porque Canguilhem me disse, e os outros teriam dito a mesma coisa: que eles achavam que ela deveria fazer uma tese e entrar na universidade.

Luciana Portela: Essa então teria sido uma opção pessoal dela?

Alain Badiou: Era ela mesma, e eu acho que você está mais bem posicionada que eu para saber, que era também uma herança da história brasileira. Da recusa que ela havia sofrido no Brasil, do fato que tinha terminado mal, tudo isso. De que a sua área de atividade era a antropologia... E que ela não queria mais ouvir falar! Tudo isso bloqueou o seu caminho, mas eu acho que esse caminho teria sido aberto. Eu posso afirmar que, se tivesse tido uma tese de Dina Dreyfus, a sala estaria repleta de homens admiradores.

Luciana Portela: Ao longo da minha pesquisa na França, compreendi que, no seu caso específico, era ela que havia feito a escolha de se dedicar ao ensino da filosofia, seguir nessa direção.

Alain Badiou: Eu estou de acordo com você, porque garanto que ela teve essa possibilidade. Os grandes regentes da universidade não a teriam barrado. E olha que eles eram, muito frequentemente, um tanto misóginos! Se você pegar Canguilhem, ele era um pouco misógino. Não há dúvidas! Ele não tratava igualmente as estudantes e os estudantes. Ele não se dava conta, mas nós, nós percebíamos. Ele tinha tendência a partir da ideia de que uma moça não tinha sido feita para a filosofia. Ele não o dizia, mas a gente sentia. Mas, justamente, ele não pensava isso de Dina. Sobre a Dina, ele me disse, ele teria apoiado o seu trajeto para entrar na universidade. Isso reforça a ideia de que ela ocupou uma posição totalmente excepcional, na qual ela 
estava rodeada por todo o mundo filosófico francês. Ela conhecia todo mundo nesse meio, era admirada, altamente considerada por todo mundo. Incluindo eu, mas eu era o "caçula" (risos).

Luciana Portela: Mas é uma pena que ela tenha feito tantas coisas e que tão pouco tenha sido dito sobre ela.

Alain Badiou: Sim, mas, você entende, ela não quis uma obra. Eu acho, sinceramente, que houve um drama na sua vida, o drama brasileiro. E que tinha um "antes" e um "depois". E “depois”, tem um elemento de renúncia ao "antes”. Com todas essas coisas que aconteceram no Brasil, eu tenho a impressão de que, além disso, e isso deve ter agravado as coisas, o fato de ela estar ao lado de Lévi-Strauss teve um papel muito importante em todo o período brasileiro. Do ponto de vista do trabalho, das pesquisas, e das condições materiais difíceis. Eu acho, então, que isso tornava a ruptura ainda mais desagradável. Tudo o que ela tinha investido... para, ao final, ouvir: “está bem, mas eu não te amo mais"... não deve ter sido fácil... é violento!

Luciana Portela: Depois ele foi para os Estados-Unidos, quando a Guerra eclodiu, ela preferiu ficar, foi para Montpellier, usou outro nome, ao que parece, para continuar a ensinar Filosofia.

Alain Badiou: Com todos os problemas da posição dos judeus durante a guerra e apesar disso, entre aqueles que ficaram e aqueles que partiram, tinha também uma dificuldade. Aqueles que enfrentaram a situação local, como você falou, a clandestinidade, mudança de nome... Ela ficou numa situação muito difícil.

Recebido: 30/06/2018

Aprovado: 09/09/2018 
Luciana Magalhães Portela é professora do curso de Museologia da Universidade de Brasília (FCI/UnB) e doutoranda do Programa de Pós-Graduação em Antropologia Social (PPGAS-DAN/UnB). Fez sua graduação em Antropologia na UnB e o mestrado em Museologia na Universidade de Neuchâtel, na Suíça. Tem interesse em temas como a história da Antropologia, museus e coleções etnográficos e a atuação de mulheres na produção e na divulgação do conhecimento. ORCID: 0000-0002-7832-6225. Contato: lucianaportela@gmail.com

\section{Notas}

1. Esta entrevista contou com a participação de Isabelle Vodoz. Agradeço muito a sua contribuição, mediação e atenção, trazendo questões pertinentes e bem colocadas. Agradeço também a disponibilidade, generosidade e abertura de Alain Badiou. A tradução da entrevista foi feita por mim, com releitura atenciosa de Julia Henning e da Professora Doutora Ana Lúcia de Abreu (UnB), a quem agradeço igualmente.

2. O percurso de Dina Dreyfus é o foco da minha pesquisa de Doutorado no Programa de Pós- Graduação em Antropologia Social/Universidade de Brasília, orientada pelo Prof. Dra. Soraya Resende Fleischer (UnB) e coorientação do Prof. Dr. Octave Debary (Université Paris Descartes / CANTHEL).

3. CORREAA, Mariza. 2003. Antropólogas e Antropologia. Belo Horizonte: Ed. da UFMG.

4. VALENTINI, Luísa. 2010. Um laboratório de antropologia: o encontro entre Mário de Andrade, Dina Dreyfus e Claude Lévi-Strauss (1935-1938). Dissertação [Mestrado em Antropologia]. São Paulo: Universidade de São Paulo.

5. SOMBRIO, Mariana Moraes de Oliveira. 2014. Em busca pelo campo: ciências, coleções, gênero e outras histórias sobre mulheres viajantes no Brasil em meados do século XX. Tese [Doutorado em Política Científica e Tecnológica]. Campinas: Universidade Estadual de Campinas; "Os museus, as mulheres e a participação de estudos etnológicos no Brasil: aspectos contextuais no início do século XX”. In: Museologia e Interdisciplinaridade, v. 7, n. 13, jan/jun de 2018.

6. GRUPIONI, Luis Donisete Benzi. 1998. Coleções e expedições vigiadas: os etnólogos no conselho de fiscalização das expedições artísticas e cientificas no Brasil. São Paulo: Hucitec/Anpocs.

7. Arquivos audiovisuais e publicações dos programas da RTS disponíveis na página internet da Biblioteca Nacional francesa; relatos de ex-alunos e colegas do período em que foi professora e inspetora de filosofia, junto a seus artigos reunidos em livro póstumo publicado por Christiane Menasseyre e Bertrand Saint-Sernin (DREYFUS, Dina. 2013. Écrits. Paris: Hermann); referências à sua atuação na série de Filosofia da RTS em programas de rádio, artigos de jornal, obras dedicadas ao ensino da filosofia na França, entre outras fontes.

8. Dreyfus concebeu a série de Filosofia inspirada nos diálogos de Platão, tendo como objetivo apresentar aos alunos secundaristas uma comunidade de filósofos vivos.

9. Mais de 40 emissões de televisão dedicadas à Filosofia foram produzidas entre 1964 e 1970.

Dentre elas, ao menos um quarto contou com a parceria entre Badiou e Dreyfus. Só no primeiro 
ano do programa, em 1964, foram realizados 7 episódios de duração aproximada entre 30 e 40 minutos: 6 episódios tratam de temáticas distintas, além de um episódio de síntese, onde Dreyfus retoma as principais questões debatidas nos anteriores. O episódio de síntese é também um programa dedicado a responder às críticas e observações de professores de Filosofia do ensino secundário, que haviam realizado um encontro, organizado pela Inspetora, com o objetivo de analisar a eficácia e os limites do método. Informações e vídeos disponíveis em: https: / gallica.bnf.fr. Acesso em: 25 set. 2018.

10. Texto de apresentação das séries da RTS, disponível em: https: / /gallica.bnf.fr/html/und/ videos/series-de-la-radio-television-scolaire. Acesso em: 26 set. 2018.

11. Título que recebe quem realiza com sucesso a Agrégation, concurso do sistema de ensino francês que dá o direito à admissão no corpo dos professores do ensino secundário ou superior.

12. Lycée é a instituição do sistema educacional francês que equivale ao Ensino Médio no Brasil.

13. Informações retiradas de: https: / / alain-badiou.jimdo.com/. Acesso em: 25 set. 2018.

14. BADIOU, Alain. 1994. Para uma nova teoria do sujeito: conferências brasileiras. 2. ed. Rio de Janeiro: Relume Dumará.

15. BADIOU, Alain. 1996. O ser e o evento. Rio de Janeiro: Jorge Zahar.

16. BADIOU, Alain. 2007. O século. São Paulo: Idéias \& Letras.

17. BADIOU, Alain. 2018. On a raison de se révolter! L'actualité de Mai 68. Paris: Fayard.

18. Entrevista com Alain Badiou. Disponível em: https://www.franceculture.fr/emissions/ la-grande-table-2eme-partie/revoltons-nous-avec-alain-badiou e7f6bed0446cdf8da. Acesso em: 25 set. 2018.

19. VODOZ, Isabelle; TARBY, Fabien (Orgs.). 2011. Autour d'Alain Badio. Paris: Germina.

20. BADIOU, Alain. 2014. A República de Platão recontada por Badiou. Rio de Janeiro: Zahar.

21. Jean Fléchet.

22. Último ano do Lycée.

23. Grupioni (1998); Corrêa (2003); Valentini (2010); Sombrio (2014, 2018), já referenciados nas notas 2, 3, 4, e 5 .

24. CENTRE NATIONAL DE DOCUMENTATION PÉDAGOGIQUE. 1995. "Sartre par la méthode Cogito”. Téléscope, n. 102, p. 9. (Disponível em: https: / gallica.bnf.fr). Acesso em: 21 set. 2018.

25. Disponível em: https://www.srf.ch/sendungen/sternstunde-philosophie/alain-badiou-raus-aus-der-komfortzone. Acesso em: 04 out. 2018.

26. CHAPLIN, Tamara. 2007. Turning on the mind, French Philosophers on Television. Chicago: The University of Chicago Press.

27. DREYFUS, Dina. 2013. Écrits. Paris: Hermann. 